\title{
OBSERVATIONS ON INNOVAR AS PREOPERATIVE MEDICATION*
}

\author{
GoRDON M. WYANT, C.D., M.D., F.R.C.P.(c), F.F.A.R.C.S., AND \\ Gerald B. H. LEWIS, M.B., B.S., D.A. (R.C.P. \& S.) $\uparrow$
}

IT WAS TO BE EXPECTED that the increasing popularity of the neuroleptanalgesic mixture of fentanyl and droperidol, known by the trade name of Innovar should have called, in due course, for its evaluation as a preoperative sedative-analgesic. We were not alone in this realization and indeed a paper has been published in this Journal ${ }^{1}$ dealing with this very subject. However, while that study related solely to observations on 121 adult patients premedicated with Innovar, our study was conceived as a comparison of Innovar with both the standard premedicant meperidine and with a placebo.

\section{METHOD}

The study was set up as a double-blind evaluation using 150 coded $2 \mathrm{ml}$ ampoules, 50 each containing respectively droperidol $2.5 \mathrm{mg}$ with fentanyl 0.05 $\mathrm{mg} / \mathrm{ml}$, meperidine $50 \mathrm{mg} / \mathrm{ml}$, or the placebo. The code was retained by the hospital pharmacy and was not broken by us until after the termination of the study. Patients booked for general anaesthesia were selected at random from the daily operating slate except that neurosurgical, cardiac, ophthalmological and paediatric cases were excluded. Excluded also were patients in any physical status lower than 2. On the other hand, emergency cases in physical status equivalent to 1 and 2 were accepted into the study. One single investigator was assigned to supervise all administrations and to evaluate their effects. He was not the anaesthetist assigned to the case, however, so that it was possible to have subjective parameters evaluated both by the investigator and by the anaesthetist. Belladonna derivatives were not administered during the phase of evaluation but were given intravenously after all observations had been concluded, immediately before induction of anaesthesia, if in the opinion of the anaesthetist this was considered desirable. Prior to the administration of the coded premedication, each patient was evaluated on the basis of nine criteria, namely whether he or she was alert, calm, drowsy, apprehensive, restless, or euphoric, whether there were complaints of dizziness, nausea, or actual vomiting. Systolic and diastolic blood pressure and pulse rate also were noted. The coded drug was then administered intramuscularly on the basis of $1 \mathrm{ml}$ for the first 150 pounds of body weight with increments of $0.1 \mathrm{ml}$ for each additional 15 pounds. The minimum dose administered, irrespective of weight, was $1 \mathrm{ml}$. The mean amount of Innovar resulting from this dosage was $1.09 \mathrm{ml}$; that of meperidine $1.05 \mathrm{ml}$; and that of

\footnotetext{
'Presented at the Annual Meeting of the Canadian Anaesthetists' Society, King Edward Sheraton Hotel, Toronto, June 18, 1969.

tDepartment of Anaesthesia, University of Saskatchewan and University Hospital, Saskatoon, Saskatchewan.
} 
placebo $1.08 \mathrm{ml}$. Following premedication, systolic and diastolic blood pressure and pulse rate were recorded every 10 minutes for a maximum period of 120 minutes, while the subjective criteria enumerated above were reassessed at $30,60,90$, and 120 minutes. A period of observation of 60 minutes was considered minimum for retention of any particular patient in the study. At the end of the period of observation, the anaesthetist was asked to evaluate the premedication from his point of view, and the patient's acceptance of the premedication was ascertained later whenever possible. On some occasions the patient was sent for by the operating room before the minimum of 60 minutes had elapsed. The pharmacy department was requested to replace the ampoules used on discarded cases at the end of the study, so that they could be reused on other patients.

\section{RESULTS}

\section{Baseline data}

Table I lists the patient characteristics for each drug group, and it is evident that they are quite similar for each of the parameters listed. Therefore it is possible to make valid comparisons between Innovar, meperidine, and the placebo in respect to all subsequent observations.

TABLE I

Patient Characteristics

\begin{tabular}{|c|c|c|c|c|c|c|c|}
\hline \multirow{2}{*}{$\begin{array}{l}\text { Drug } \\
\text { group }\end{array}$} & \multirow{2}{*}{$\begin{array}{l}\text { No. of } \\
\text { pts. }\end{array}$} & \multicolumn{2}{|c|}{ Sex } & \multirow{2}{*}{$\begin{array}{l}\text { Mean } \\
\text { age }\end{array}$} & \multirow{2}{*}{$\begin{array}{c}\text { Mean } \\
\text { weight }\end{array}$} & \multicolumn{2}{|c|}{$\begin{array}{c}\text { Physical } \\
\text { status }\end{array}$} \\
\hline & & M & $\mathrm{F}$ & & & 1 & 2 \\
\hline Innovar@ & 50 & 12 & 38 & 38.9 & 142.4 & 22 & 28 \\
\hline Meperidine & 50 & 12 & 38 & 35.4 & 143.7 & 22 & 28 \\
\hline Placebo & 50 & 19 & 31 & 42.5 & 148.3 & 21 & 29 \\
\hline
\end{tabular}

\section{Subjective data}

Patient conditions at various stages of observation are listed in Table II. It is obvious from the totals that more than one observation was recorded for a number of patients. This is because many of the nine parameters coded were not mutually exclusive. For instance, it was possible for a patient to be both alert and restless, or apprehensive and nauseated, etc. Because of such dual observations, the data presented in this table have not been subjected to statistical analysis, but even so, cursory study indicates that the three groups responded similarly except that the meperidine group had a larger percentage of euphoric patients than did either the Innovar or the placebo groups.

Considering the evaluations of "alert," "calm," and "drowsy" alone and eliminating the baseline data before administration of the drugs (Table III), there is evidence that more patients were drowsy and fewer alert following administration of Innovar than after meperidine or placebo, and that again more were drowsy and fewer alert after meperidine than after placebo. For the same reasons as above, no statistical test was applied to these data either. 
WYANT \& LEWIS: INNOVAR AS PREOPERATIVE MEDICATION

TABLE II

Patient Condition

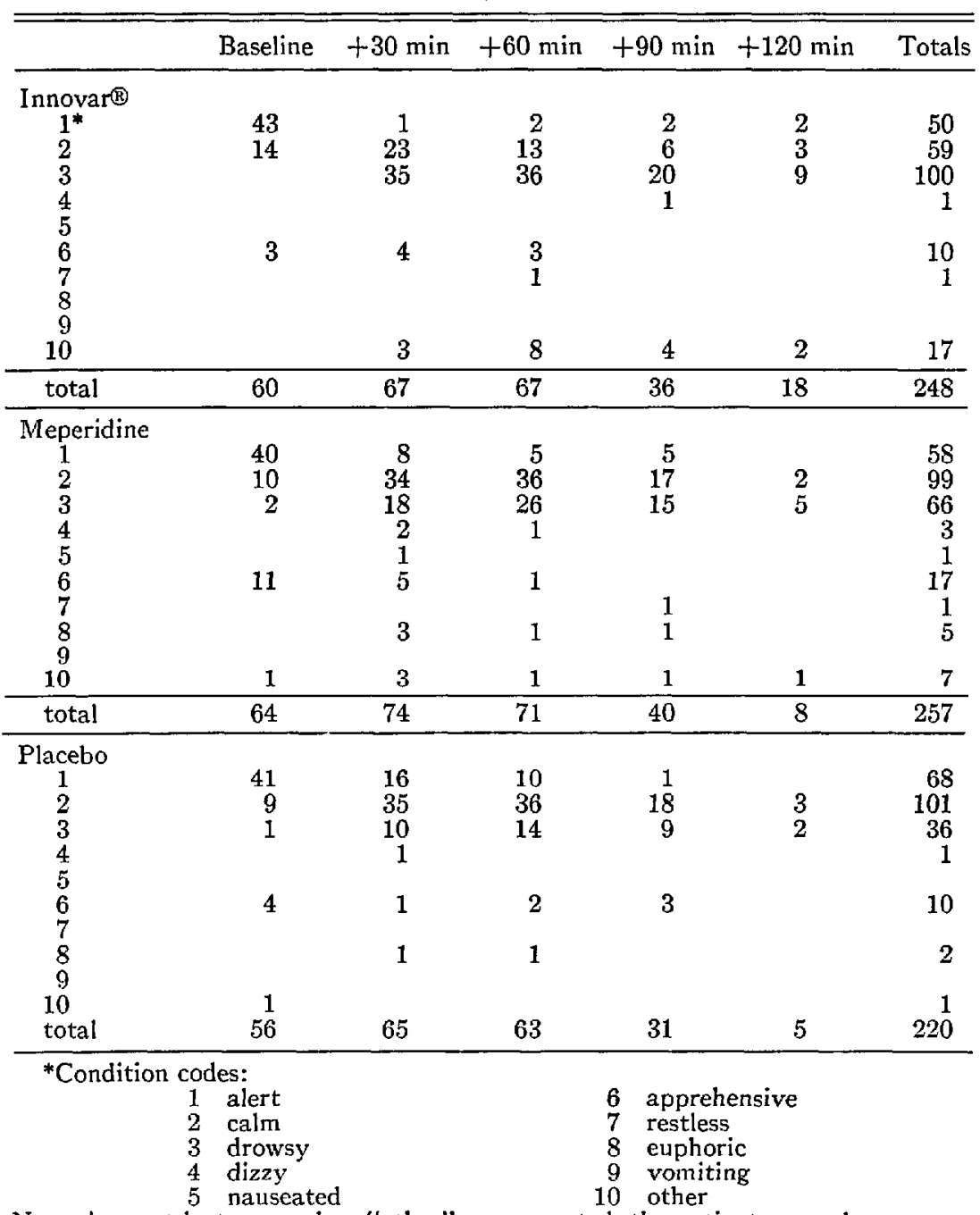

Note: in most instances when "other" was reported, the patient was asleep.

TABLE III

\begin{tabular}{lccc}
\hline & Alert & Calm & Drowsy \\
\hline Innovar & 7 & 45 & 100 \\
Meperidine & 18 & 89 & 64 \\
Placebo & 27 & 92 & 35 \\
\hline
\end{tabular}

The anaesthetists' evaluations at the time of induction are listed in Table IV. There, for both Innovar and meperidine, there is a higher proportion of good and excellent assessments than for the placebo group, where fair and poor tend to predominate. Two statistical tests were applied to this distribution. The Kruskal-Wallis non-parametric analysis of variance test indicated that the drug 
TABLE IV

Anaesthetist's Eval tation of Drug

\begin{tabular}{lcccccc}
\hline \hline Drug & Excellent & Good & Fair & Poor & Unknown & Total \\
\hline Innovar & 5 & 23 & 9 & 9 & 4 & 50 \\
Meperidine & 5 & 25 & 6 & 11 & 3 & 50 \\
Placebo & 2 & 19 & 11 & 18 & 0 & 50 \\
\hline
\end{tabular}

groups are superior to the placebo with $p<0.10$ and $>0.05$. This means that the probability of the higher percentage of excellent and good evaluations occurring by chance alone is less than .10 but greater than .05 . Identical results were obtained by applying the chi-square test to the same data.

Table V (patient acceptance) shows a pattern similar to that observed in the anaesthetist's evaluation. Again a higher proportion of excellent and good evaluation is apparent among the drug groups as opposed to the placebo group. Innovar is a little superior to meperidine, though not significantly so. The Kruskal-Wallis analysis of variance test applied to these data also shows results to be highly significant $(p<.01)$. That is to say the probability that the higher proportion of superior evaluation among the drug groups could occur by chance alone is less than 1 per cent.

TABLE V

Patient's Accleptance of Drug

\begin{tabular}{lcccccc}
\hline \hline Drug & Excellent & Good & Fair & Poor & Unknown & Total \\
\hline Innovar & 7 & 31 & 2 & 4 & 6 & 50 \\
Meperidine & 5 & 29 & 2 & 6 & 8 & 50 \\
Placebo & 3 & 22 & 8 & 12 & 5 & 50 \\
\hline
\end{tabular}

\section{Objective data}

The results of observations of vital signs are contained in Table VI. The predrug baseline values for each parameter were compared between drugs and the placebo to determine if the groups were homogeneous. They were found to be so in all parameters. Then each parameter was tested independently for each drug and placebo to determine whether a significant change occurred. In certain instances the changes were statistically significant, but in order to appreciate these and their time relationships better, some of the data derived from Table VI have been plotted graphically.

On studying the behaviour of the mean systolic blood pressure (Fig. 1), the significant fall in blood pressure for both Innovar and meperidine is apparent. However, the difference between them is that the maximum depression of systolic pressure following Innovar occurs at the 30 and 40 minute stage followed by a minor recovery, whereas the greatest degree of depression after meperidine occurs at the 80 to 90 minute stage. Changes after the placebo are statistically not signifiicant.

The mean diastolic blood pressure (Fig. 2) shows a similar time relationship as far as meperidine is concerned, but in the case of Innovar the maximum depression occurs 10 minutes later than the systolic drop with complete return to baseline at the end of 90 minutes. In this case only the decrease with Innovar 
WYANT \& LEWIS: INNOVAR AS PREOPERATIVE MEDICATION

TABLE VI

ANALysis of VITAL SignS

\begin{tabular}{|c|c|c|c|c|c|c|c|c|c|}
\hline & \multicolumn{3}{|c|}{ Systolic blood pressure } & \multicolumn{3}{|c|}{ Diastolic blood pressure } & \multicolumn{3}{|c|}{ Pulse } \\
\hline & Innovar ${ }^{\circledR}$ & $\begin{array}{l}\text { meperi- } \\
\text { dine }\end{array}$ & placebo & Innovar (1) & $\begin{array}{l}\text { meperi } \\
\text { dine }\end{array}$ & placebo & Innovar ${ }^{(1)}$ & $\begin{array}{l}\text { meperi } \\
\text { (8) dine }\end{array}$ & placebo \\
\hline $\begin{array}{l}\text { nitial value } \\
70 \text { of initial } \\
\text { D }\end{array}$ & $\begin{array}{l}118.5 \\
100 \\
18.2\end{array}$ & $\begin{array}{l}118.1 \\
100 \\
14.5\end{array}$ & $\begin{array}{l}123.6 \\
100 \\
19.0\end{array}$ & $\begin{array}{c}73.3 \\
100 \\
11.2\end{array}$ & $\begin{array}{c}73.7 \\
100 \\
11.6\end{array}$ & $\begin{array}{l}77.3 \\
100 \\
12.7\end{array}$ & $\begin{array}{l}77.4 \\
100 \\
12.4\end{array}$ & $\begin{array}{l}78.0 \\
100 \\
13.1\end{array}$ & $\begin{array}{c}76.7 \\
100 \\
9.1\end{array}$ \\
\hline $\begin{array}{l}+10 \text { min mean } \\
\% \text { of initial } \\
\text { SD }\end{array}$ & $\begin{array}{r}113.4 \\
95.7 \\
17.7\end{array}$ & $\begin{array}{r}114.2 \\
96.7 \\
14.5\end{array}$ & $\begin{array}{r}120.8 \\
97.7 \\
18.5\end{array}$ & $\begin{array}{l}72.2 \\
98.4 \\
10.8\end{array}$ & $\begin{array}{l}72.3 \\
98.1 \\
11.4\end{array}$ & $\begin{array}{l}76.3 \\
98.7 \\
12.8\end{array}$ & $\begin{array}{l}76.1 \\
98.3 \\
12.3\end{array}$ & $\begin{array}{c}78.1 \\
100 \\
13.1\end{array}$ & $\begin{array}{r}75.3 \\
98.2 \\
8.4\end{array}$ \\
\hline $\begin{array}{l}+20 \text { min mean } \\
\% \text { of initial } \\
\text { SD }\end{array}$ & $\begin{array}{r}108.1 \\
91.2 \\
16.5\end{array}$ & $\begin{array}{r}111.8 \\
94.7 \\
14.8\end{array}$ & $\begin{array}{r}115.5 \\
93.4 \\
17.6\end{array}$ & $\begin{array}{l}69.3 \\
94.4 \\
10.4\end{array}$ & $\begin{array}{l}70.9 \\
96.2 \\
11.2\end{array}$ & & & $\begin{array}{l}76.8 \\
98.5 \\
13.2\end{array}$ & $\begin{array}{r}75.1 \\
97.9 \\
9.2\end{array}$ \\
\hline $\begin{array}{l}+30 \text { min mean } \\
\% \text { of initial } \\
\text { SD }\end{array}$ & $\begin{array}{r}104.7 \\
88.4 \\
14.7\end{array}$ & $\begin{array}{r}110.9 \\
93.5 \\
15.7\end{array}$ & $\begin{array}{r}116.0 \\
93.8 \\
18.7\end{array}$ & $\begin{array}{r}67.6 \\
92.1 \\
9.9\end{array}$ & & & & & $\begin{array}{r}74.3 \\
96.9 \\
8.2\end{array}$ \\
\hline $\begin{array}{l}+40 \text { min mean } \\
\% \text { of initial } \\
\text { SD }\end{array}$ & $\begin{array}{r}104.0 \\
87.8 \\
14.1\end{array}$ & $\begin{array}{r}110.2 \\
93.3 \\
16.3\end{array}$ & $\begin{array}{r}116.1 \\
93.9 \\
19.7\end{array}$ & $\begin{array}{l}66.1 \\
90.1 \\
10.2\end{array}$ & & & & $\begin{array}{l}76.1 \\
97.6 \\
11.5\end{array}$ & $\begin{array}{r}74.8 \\
97.5 \\
8.1\end{array}$ \\
\hline $\begin{array}{l}+50 \text { min mean } \\
\% \text { of initial } \\
\text { SD }\end{array}$ & $\begin{array}{r}105.0 \\
88.6 \\
13.8\end{array}$ & $\begin{array}{r}110.1 \\
93.2 \\
15.7\end{array}$ & & $\begin{array}{r}66.6 \\
90.7 \\
9.2\end{array}$ & & & & $\begin{array}{l}76.1 \\
97.6 \\
12.1\end{array}$ & $\begin{array}{r}75.3 \\
98.2 \\
8.9\end{array}$ \\
\hline $\begin{array}{l}+60 \text { min mean } \\
\% \text { of initial } \\
\text { so }\end{array}$ & $\begin{array}{r}105.2 \\
88.8 \\
14.8\end{array}$ & $\begin{array}{r}110.4 \\
93.5 \\
15.2\end{array}$ & $\begin{array}{r}118.3 \\
95.7 \\
20.1\end{array}$ & $\begin{array}{r}69.1 \\
94.1 \\
9.9\end{array}$ & $\begin{array}{l}71.9 \\
97.6 \\
12.6\end{array}$ & & $\begin{array}{l}72.1 \\
93.1 \\
14.5\end{array}$ & $\begin{array}{l}74.1 \\
95.0 \\
13.3\end{array}$ & $\begin{array}{l}75.8 \\
98.8 \\
10.2\end{array}$ \\
\hline $\begin{array}{l}+70 \text { min mean } \\
\% \text { of initial } \\
\text { SD }\end{array}$ & $\begin{array}{r}106.3 \\
89.7 \\
14.6\end{array}$ & $\begin{array}{r}108.9 \\
92.2 \\
15.6\end{array}$ & $\begin{array}{r}117.2 \\
94.8 \\
17.9\end{array}$ & $\begin{array}{l}69.6 \\
94.8 \\
10.6\end{array}$ & $\begin{array}{r}71.3 \\
96.7 \\
9.9\end{array}$ & $\begin{array}{l}74.4 \\
96.2 \\
12.5\end{array}$ & $\begin{array}{l}71.4 \\
92.2 \\
16.4\end{array}$ & $\begin{array}{l}71.9 \\
92.2 \\
13.7\end{array}$ & $\begin{array}{r}76.8 \\
100.1 \\
10.9\end{array}$ \\
\hline $\begin{array}{l}+80 \text { min mean } \\
\% \text { of initial } \\
\text { SD }\end{array}$ & $\begin{array}{r}106.3 \\
89.7 \\
12.2\end{array}$ & $\begin{array}{r}104.1 \\
88.1 \\
15.1\end{array}$ & $\begin{array}{r}117.5 \\
95.1 \\
19.5\end{array}$ & & $\begin{array}{l}68.2 \\
92.5 \\
10.4\end{array}$ & & $\begin{array}{r}67.9 \\
87.7 \\
8.0\end{array}$ & $\begin{array}{l}69.1 \\
88.6 \\
12.4\end{array}$ & $\begin{array}{r}74.7 \\
97.4 \\
9.4\end{array}$ \\
\hline $\begin{array}{l}+90 \text { min mean } \\
\% \text { of initial } \\
\text { SD }\end{array}$ & $\begin{array}{r}106.1 \\
89.5 \\
12.8\end{array}$ & $\begin{array}{r}102.9 \\
87.1 \\
14.5\end{array}$ & $\begin{array}{r}117.2 \\
94.8 \\
18.5\end{array}$ & $\begin{array}{l}73.3 \\
99.9 \\
10.5\end{array}$ & $\begin{array}{l}67.8 \\
92.0 \\
13.6\end{array}$ & $\begin{array}{l}75.1 \\
97.2 \\
12.2\end{array}$ & $\begin{array}{r}68.5 \\
88.5 \\
8.6\end{array}$ & $\begin{array}{l}67.4 \\
86.4 \\
10.2\end{array}$ & $\begin{array}{l}73.9 \\
96.3 \\
10.1\end{array}$ \\
\hline
\end{tabular}

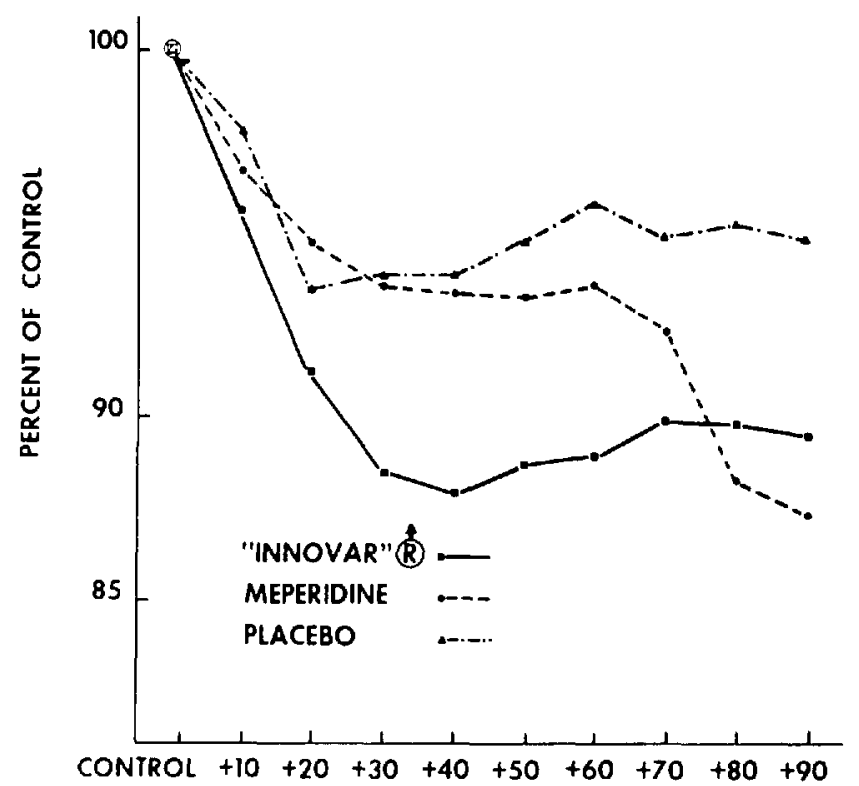

Figure 1. Mean systolic blood pressure. 


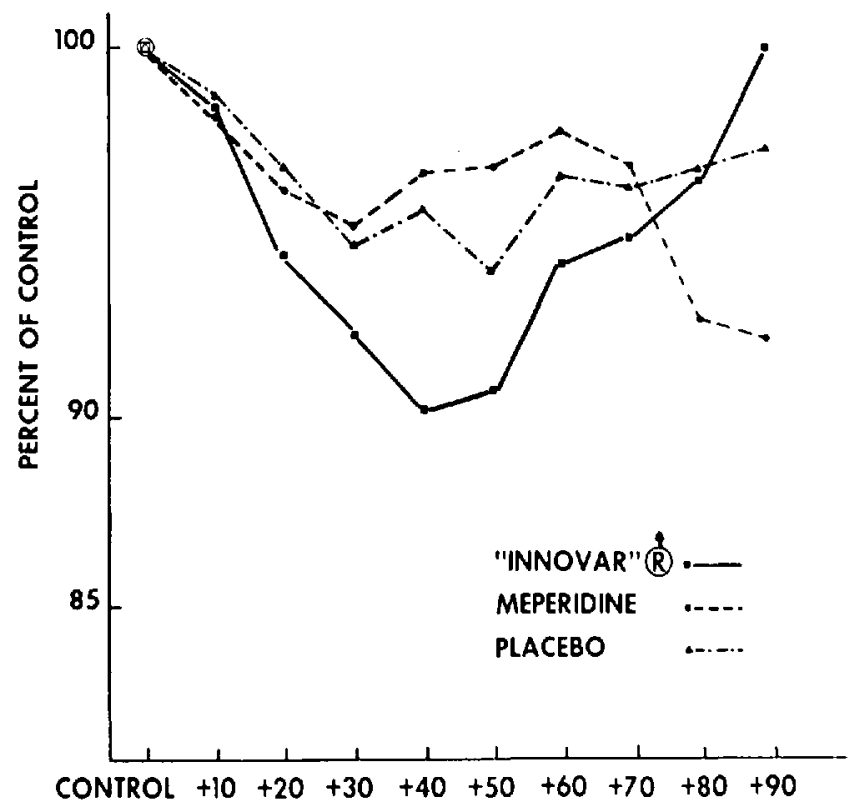

Figure 2. Mean diastolic blood pressure.

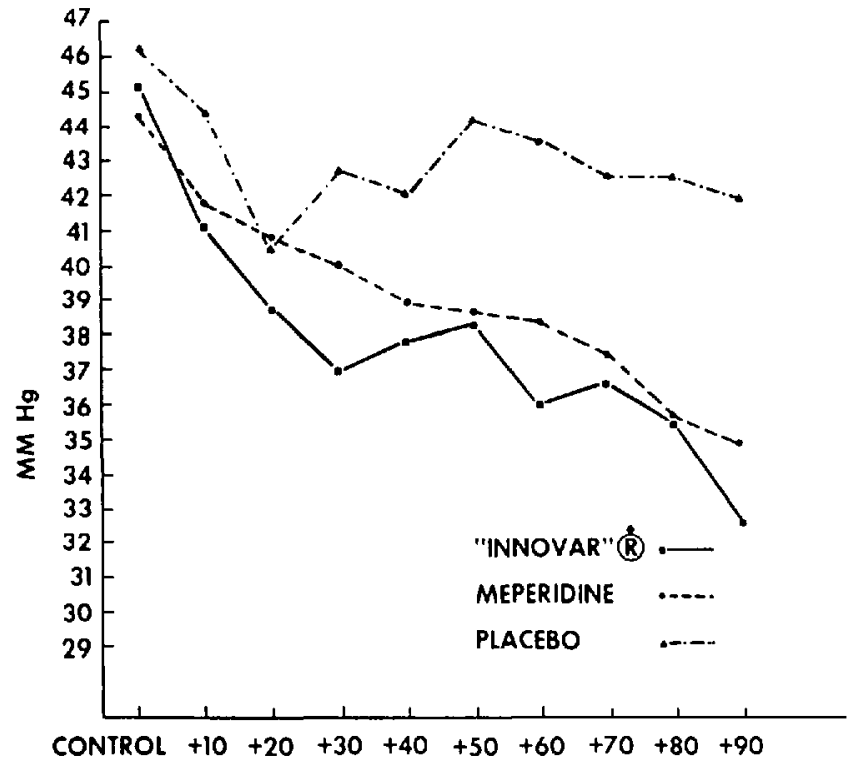

Figure 3. Mean pulse pressure.

is statistically significant, whereas the changes following meperidine and the placebo are statistically not significant.

Having observed this behaviour of systolic and mean diastolic blood pressure, it was thought advisable also to plot the mean pulse pressure (Fig. 3). The interesting feature here is that there is a progressive narrowing of the pulse pressure over the entire 90 minutes of observation following both Innovar and meperidine. 


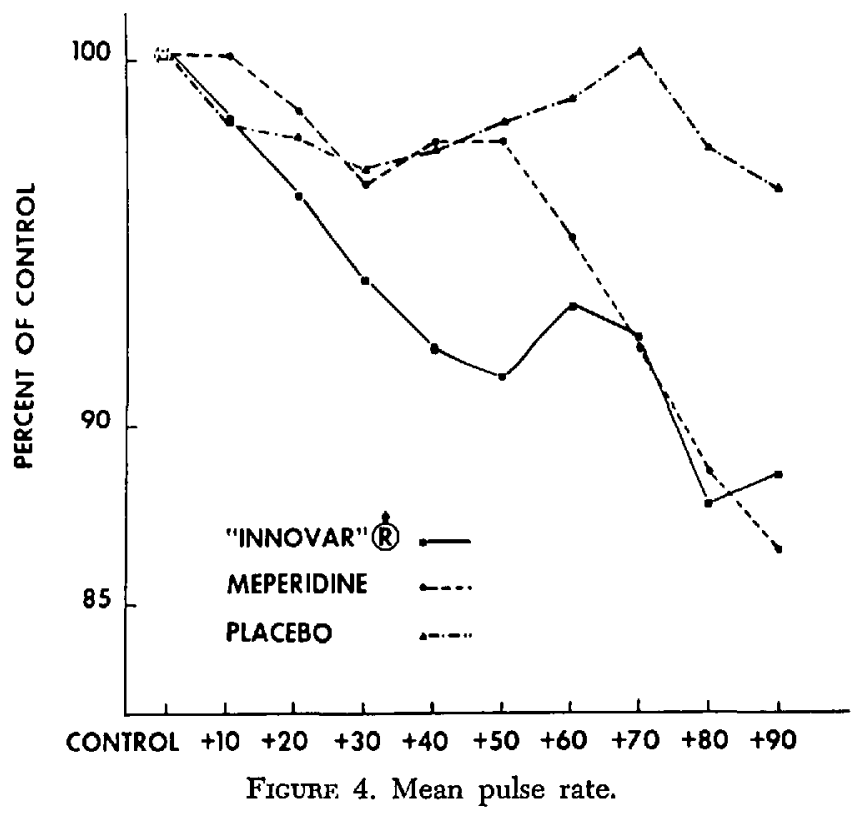

These decreases, occurring between baseline and final readings, are statistically significant $(p<.05)$. Changes for the placebo again are not significant.

As far as the mean pulse rate is concerned (Fig. 4) there is a significant decrease over the 90 minute period after both Innovar and meperidine; yet again the greatest decrease in the Innovar series comes earlier than that following meperidine. Changes in the placebo series are statistically not significant.

\section{SUMMARY}

Innovar has been compared with meperidine and a placebo in a blind study on 150 surgical patients. Both subjective and objective data were recorded, tabulated, and analysed statistically after it had been ascertained that the three groups were comparable from the point of view of sex distribution, mean age, mean weight, physical status, and baseline vital signs.

It was found that more patients were drowsy after Innovar than after meperidine and that the same applied to meperidine when compared with the placebo. From the anaesthetist's point of view, Innovar and meperidine were better sedatives than the placebo, and this was also the impression of most patients.

As far as objective parameters were concerned, there was a fall in both systolic and diastolic blood pressure after Innovar and in systolic blood pressure after meperidine. However, in the case of Innovar this response started with 10 minutes of the intramuscular injection with the effect progressing for approximately 30 to 40 minutes, after which time it stabilized. After meperidine no major changes were seen for 60 minutes, but then the systolic blood pressure declined below that recorded after Innovar. There was a sustained decrease in mean pulse pressure throughout the period of observation after both Innovar and meperidine. The mean pulse rate after Innovar tended to fall throughout the 
period of observation whereas that following meperidine remained essentially unchanged for the first 50 minutes and then fell rapidly to levels similar to those seen with Innovar. With the exception of the diastolic blood pressure after meperidine, all changes were found to be statistically significant, but no significant changes occurred after placebo in any parameter.

\section{RÉSUMÉ}

Chez 150 candidats à la chirurgie, nous avons comparé, à l'aveugle, l'Innovar, la mépéridine et un placebo. Nous avons enregistré les données objectives et subjectives, nous les avons placées en tableaux, nous en avons fait une analyse statistique après nous être assurés que les trois groupes étaient comparables du point de vue du sexe, de l'âge moyen, du poids moyen, de l'état physique et des signes vitaux de base.

Nous avons constaté qu'un plus grand nombre de malades étaient étourdis après l'innovar qu'après la mépéridine et la même observation tient pour la mépéridine et le placebo. Du point de vue de l'anesthésiste l'Innovar et la mépéridine ont été de meilleurs sédatifs que le placebo et ce fut la même impression pour la plupart des malades.

En ce qui concerne les paramètres objectifs: après l'Innovar, nous avons observé une chute des pressions systolique et diastolique et, après la mépéridine, de la systolique seulement. Toutefois, dans le cas de l'Innovar, cette manifestation est apparus en deça de 10 minutes de l'injection intramusculaire et l'effet a augmenté durant environ 30 à 40 minutes, puis, il s'est stabilisé. Après la mépéridine on a noté aucun changement durant 60 minutes, puis, alors la tension systolique s'est abaissée à des chiffres inférieurs à ceux observés après l'Innovar. Après les deux médicaments: Innovar et mépéridine, il y a eu une diminution persistante de la pression différentielle moyenne durant la période d'observation. Après l'Innovar, la fréquence moyenne du pouls a plutôt diminué durant la période d’observation alors qu'avec la mépéridine, elle est demeurée sans changement durant les 50 premières minutes et, alors, elle s'est abaissée rapidement au niveau des chifres produits par l'Innovar. A l'exception de la pression diastolique après la mépéridine, toutes les modifications ont une valeur statistique; cependant, après le placebo, aucune modification n'est apparue sur aucun paramètre.

\section{ACKNOWLEDGMENTS}

The authors wish to acknowledge the assistance of Larry J. Gelmon, B.A., in the preparation of this article. They are indebted to McNeil Laboratories (Canada) Ltd. for a grant-in-aid in support of this study and to Mr. T. W. Teal of the Science Information Division of McNeil Laboratories, Fort Washington, Pennsylvania, for tabulation and statistical analysis.

\section{REFERENCES}

1. Catron, D. V. \& Browne, R. A. Premedication with Fentanyl and Droperidol. Canad. Anaesth. Soc. J. 16: 72 (1969). 